\author{
Hanna Hall ${ }^{1}$, Kamila Peszko² \\ ${ }^{1}$ Politechnika Rzeszowska \\ Wydział Zarządzania \\ e-mail: hhall@prz.edu.pl \\ 2Uniwersytet Szczeciński \\ Wydział Zarządzania i Ekonomiki Usług \\ e-mail: kamila.peszko@wzieu.pl
}

\title{
Social media as a relationship marketing tool of modern university
}

JEL codes: M31, P36

Keywords: relationship marketing, trends in marketing of higher education, social media, higher education

Abstract. The aim of the article is to present selected aspects of university activities in the sphere of development of relations with its stakeholders, with particular emphasis on students, and with the use of social media as a key communication platform in the online space. The starting point for the analysis of the undertaken subject is to present the essence of relationship marketing in relation to higher education institutions as a result of adaptation and evolution of the marketing of these market players, as well as current trends in higher education marketing. In the article, secondary sources and the authors' research have been used, the object of which was to identify the scope, intensity, and professionalism of the activities of university in the area of social media.

\section{Introduction}

The concept of relationship marketing, which is one of the most popular management concepts of today's organizations, has won the dominant position also in the sector of higher education, which is the result, on the one hand, of the complex 
conditions of the functioning of modern universities and related with it uncertainty and unpredictability of action, and on the other hand, of the benefits that the above concept provides to the organizations operating in this environment and its stakeholders. When applying the concept of relationship marketing, universities adapt tools which are successfully used by companies, including the modern tools of the Internet communication with the market, among which social media play the prominent role next to the website.

Social media are variously defined in the literature. For instance, according to van Dijk (2013) "the guiding idea of social media is that of creating the content and sharing it with other users, i.e. community. It can be argued that social media allow for free communication between different communities in the network. Thus, the network society is the social group in which there is a specific structure of social and media networks, shaping the behavior of individual users at all levels."

According to Mróz-Gorgoń and Peszko (2016),"social media is a network community communication channels, allowing for the exchange of information, but also interaction or integration between network users (Internet users), or Internet users and brands. Published information is available to all users or to selected groups and undergo less or more social control."

A few years ago, until the academic year 2006/2007, Polish universities which, at that time, were not affected by the problem of demographic decline, did not have to be interested in and invest in the modern tools of creating relationships with the environment. Social networking sites were considered by the university authorities neither as important nor effective area of building and maintaining relationships with stakeholders. Currently, the use of these communication channels, which are an integral part of everyday life of candidates, students, or graduates, has become an indisputable necessity.

The aim of the article is to present selected aspects of university activity in the sphere of development of relations with its stakeholders, with particular emphasis on students, with the use social media as a key marketing communication area of these entities with the market, in the online environment.

\section{Relationship marketing as a result of universities marketing evolution}

Marketing of higher education as a separate discipline emerged in the United States in the mid-80s of the last century, as a result of unfavorable demographic trends. According to Kotler and Fox (1995, pp. 11-12), universities in the US and in Western Europe went through a series of steps of their adaptation of treating marketing as a promotion, by segmenting the market, implementation of marketing research, positioning the university, the strategic dimension of marketing, 
and relationship marketing (referring to the relationship with the students), and then incuding other groups of beneficiaries (Bjørkquist, 2007; Kuzu, Gökbel, Güleş, 2013; Mainarde, 2010).

Taking into account similar, but a significantly time shifted process of adaptation of marketing at Polish universities, one should also pay attention to:

- a larger increase in interest of the university authorities and opinions of students on didactics, academic teachers, and their satisfaction with the studies (e.g. due to unfavorable demographic changes), implying the implementation of formal research in this area,

- intensive efforts to adapt the "product" (majors) to the expectations of the candidates, students, and the labor market,

- interest in the needs and expectations of all stakeholders of the university, and the desire to maintain a stable and win-win relationships which reflect the essence of relationship marketing.

Relationship marketing as for the higher education institution can be defined as the totality of activities of universities, whose aim is to create long-term and strong partnerships with individual groups of its stakeholders (including candidates, students, alumni, employees, business representatives, local authorities), which are based upon the satisfaction of individual groups, and as its consequence -"exceptional loyalty" (expressing a positive attitude and behavior, being reflected, among others, in the conscious continuing cooperation and recommending the university) (Hall, 2014).

The idea of relationship marketing seems to be still, according to the analysis of Western literature related to the subject, the guiding idea in the management of modern universities. However, the tools used within this idea are changing, as well as the means and methods of achieving the objectives and the personal scope of the relationship. They concern all - internal and external stakeholders, and not just university students.

\section{Trends in higher education marketing}

One of the most important trends in marketing of universities and their branding is the fact that they have become the subject of greater attention and interest of University authorities than in previous years (Trends in higher education..., 2014).

"Many universities have hired marketing professionals from the corporate world and invested significant time and money to create strong institutional brands" (Trends in higher education..., 2014). In some cases, such as at Northwestern University in the US, this has meant creating Chief Marketing Officer (CMO) 
positions, and making brand creation and marketing campaigns a core function of the institution (Morrison, 2013).

Information technologies are the most important area of innovation and growth in university marketing with special attention to recruitment. Trends in marketing of universities and their use reflect in (Noaman, 2012; Joly, 2012; Dixon, 2012; Trends in higher education..., 2014):

- responsive (intuitive and easy to navigate) website design, that can be viewed on multiple devices and platforms,

- $\quad$ search engine optimization (SEO) - administrators want their institutions to receive a prominent spot in search engine results, particularly Google,

- use of web analytics - universities are relying on data-driven analytics to determine who, how, and where they are reaching their audiences,

- mobile development - universities are making greater investments in having a mobile presence (not only mobile versions of websites, but also making a greater amount of course content mobile-friendly),

- CMS and CRM systems - universities are relying more heavily on content management and customer relations systems (CRM systems are especially important tools for admissions professionals engaged in outreach to prospective students).

Modern universities do not use the full potential of information technology. This includes the area of social media. As it results from the research conducted by University of Massachusetts Dartmouth, almost all universities take advantage of the selected forms within both marketing and non-marketing nature of daily activity (Trends in Higher Education..., 2014).

\section{Social Media as the dominant tool for creating relationships with students}

Nowadays, the priority role of students as stakeholders, from a marketing point of view, is the result of many causes, including primarily the impact of their opinion on the university image, which is one of the most important of its assets, but also on the decisions of candidates associated with the choice of university. Sharing opinions among students, universities recommendations, or discouraging to take studies is now very popular, quick, and easy, thanks to social networks and blogs.

Social media are of particular importance among university inbound marketing tools. Both in Western countries and in Poland, they are now a key component of the university communication with stakeholders. According to Chwiałkowska (2013), being on Facebook and intensive communication (mostly with students) is now a standard at Polish universities, and positive effects of communication on this and other sites are reflected by the fact that the average rate of user involvement 
("the number of people who talk about it") is many times higher than the same indicator for companies profiles.

As presented in the results of research carried out for the purpose of doctoral dissertation of one of the authors, as early as in 2013, most universities used social media, with Facebook as the most popular as it was on $96.4 \%$ of the main sites of Polish universities (there are also several units that had an account on Facebook, but did not have a tag on their website). The second social medium, which can be found on $32.3 \%$ of the sites of universities, is YouTube, serving as a place to post short commercials of these units, now also materials from the ceremonies, from classes or for classes. The third type of social media, with $18 \%$ interest was Twitter (Peszko, 2013). ${ }^{1}$ The results of the research "Universities in social media 2014 "Report of Fanpage Trends - Sotrender -in the category Universities, a Facebook profile was present in $100 \%$ of public universities and $95 \%$ of private universities, a YouTube channel $-75 \%$ of public universities and $47 \%$ of private universities, and a Twitter account $-58 \%$ of public universities and $15 \%$ of private universities (Uczelnie $w$ social..., 2014). In subsequent years, the popularity of social media continued to grow. Apart from these media, other forms of social media have gained popularity among universities, i.e. Instagram, Google+, GoldenLine, Linkedin, as well as, to a lesser degree, Flickr, and Snapchat last year.

Further research, completed in 2013, whose objective was to analyze the use of social media as a channel of communication with key stakeholders, shows that students in general are satisfied with how the university profiles are run.

However, they expect more scientific, research, and related to business content, as well as the possibility of internships and jobs. Their expectations also apply to an access to lectures, teaching, and educational materials. They also expect that the profile of the university on Facebook will be the source of information on initiatives in individual departments, careers of graduates, activities of student organizations, and development opportunities offered by individual faculties. They expect reports from student exchange programs and effective communication with the university, including greater availability to the deans' offices and employees (Chwiałkowska, 2014).

The quoted research results do not indicate how many of these communication tools and social media have been used in building relationships with the students or potential candidates. The authors decided to check how social media influence building relationships, whether universities skillfully take advantage of social media in this area, and what differences are in the way of creating relationships in social media by the most popular in the year 2015/2016 universities, and by other universities not belonging to the above leaders.

\footnotetext{
1 The results of research conducted within the framework of the dissertation of K. Peszko.
} 
The analysis included selected universities, commonly chosen by candidates in the academic year 2015/2016, i.e. 16 public universities and 15 private universities, supervised by the Ministry of Science and Higher Education (MSHE) (Tegoroczni maturzyści..., 2015).

Table 1

Selected statistics of social media - public universities

\begin{tabular}{|c|c|c|c|c|c|c|c|}
\hline Universities & 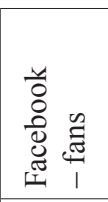 & 离军 & 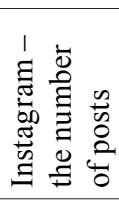 & 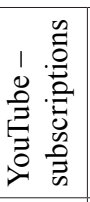 & $\begin{array}{l} \\
+ \\
0 \\
\frac{0}{0} \\
00 \\
0 \\
0 \\
0\end{array}$ & 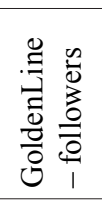 & 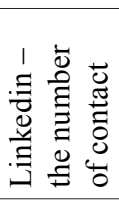 \\
\hline 1 & 2 & 3 & 4 & 5 & 6 & 7 & 8 \\
\hline Uniwersytet Warszawski & 45307 & 0 & 0 & 1036 & 0 & & 0 \\
\hline Uniwersytet w Białymstoku & 8315 & 0 & 0 & 16 & 0 & & 0 \\
\hline $\begin{array}{l}\text { Uniwersytet im. Adama } \\
\text { Mickiewicza w Poznaniu }\end{array}$ & 16638 & 0 & 0 & 332 & 0 & 27238 & 0 \\
\hline $\begin{array}{l}\text { Uniwersytet Jagielloński } \\
\text { w Krakowie }\end{array}$ & 8481 & 968 & 261 & 1226 & 283 & 0 & 0 \\
\hline Uniwersytet Łódzki & 19651 & 3567 & 60 & 280 & 15 & 27384 & 0 \\
\hline $\begin{array}{l}\text { Uniwersytet Marii Curie- } \\
\text {-Skłodowskiej w Lublinie }\end{array}$ & 32267 & 3037 & 0 & 0 & 0 & 0 & 0 \\
\hline Uniwersytet Szczeciński & 16201 & 0 & 0 & 0 & 0 & 0 & 0 \\
\hline $\begin{array}{l}\text { Uniwersytet Śląski } \\
\text { w Katowicach }\end{array}$ & 20772 & 4910 & 210 & 5071 & 296 & 0 & 247 \\
\hline Uniwersytet Rzeszowski & 8442 & 1049 & 93 & 161 & 0 & 0 & 0 \\
\hline $\begin{array}{l}\text { Uniwersytet Warmińsko- } \\
\text {-Mazurski w Olsztynie }\end{array}$ & 30372 & 123 & 112 & 1033 & 0 & 0 & 0 \\
\hline $\begin{array}{l}\text { Uniwersytet Kardynała Stefana } \\
\text { Wyszyńskiego w Warszawie }\end{array}$ & 13884 & 0 & 0 & 0 & 0 & 0 & 0 \\
\hline $\begin{array}{l}\text { Uniwersytet Jana } \\
\text { Kochanowskiego w Kielcach }\end{array}$ & 3571 & 246 & 0 & 100 & 0 & 0 & 0 \\
\hline Politechnika Warszawska & 25135 & 1234 & 220 & 55 & 0 & 0 & 310 \\
\hline $\begin{array}{l}\text { Akademia Techniczno- } \\
\text {-Humanistyczna } \\
\text { w Bielsku-Białej }\end{array}$ & 6240 & 1132 & 0 & 41 & 0 & 0 & 0 \\
\hline Politechnika Gdańska & 12512 & 0 & 96 & 609 & 0 & 0 & 231 \\
\hline $\begin{array}{l}\text { Politechnika Krakowska } \\
\text { im. Tadeusza Kościuszki }\end{array}$ & 19529 & 0 & 161 & 102 & 0 & 0 & 0 \\
\hline $\begin{array}{l}\text { Akademia Górniczo-Hutnicza } \\
\text { im. Stanisława Staszica } \\
\text { w Krakowie }\end{array}$ & 9888 & 1129 & 391 & 1175 & 0 & 27919 & 0 \\
\hline Politechnika Łódzka & 12791 & 1361 & 138 & 17 & 0 & 0 & 0 \\
\hline Politechnika Opolska & 6167 & 0 & 97 & 208 & 317 & 0 & 0 \\
\hline
\end{tabular}




\begin{tabular}{|c|c|c|c|c|c|c|c|}
\hline 1 & 2 & 3 & 4 & 5 & 6 & 7 & 8 \\
\hline Politechnika Poznańska & 13883 & 48 & 0 & 12 & 17 & 0 & 0 \\
\hline Politechnika Wrocławska & 15349 & 10600 & 391 & 8232 & 1167 & 0 & 0 \\
\hline $\begin{array}{l}\text { Uniwersytet Ekonomiczny } \\
\text { w Krakowie }\end{array}$ & 20765 & 0 & 0 & 210 & 17 & 22950 & 0 \\
\hline $\begin{array}{l}\text { Uniwersytet Ekonomiczny } \\
\text { we Wrocławiu }\end{array}$ & 20847 & 353 & 245 & 41 & 63 & 11018 & 257 \\
\hline $\begin{array}{l}\text { Akademia Pedagogiki } \\
\text { Specjalnej im. Marii } \\
\text { Grzegorzewskiej }\end{array}$ & 9695 & 473 & 25 & 118 & 8 & 0 & 54 \\
\hline $\begin{array}{l}\text { Akademia im. Jana Długosza } \\
\text { w Częstochowie }\end{array}$ & 4533 & 339 & 0 & 0 & 0 & 0 & 0 \\
\hline $\begin{array}{l}\text { Uniwersytet Pedagogiczny } \\
\text { im. Komisji Edukacji Narodowej } \\
\text { w Krakowie }\end{array}$ & 12105 & 516 & 0 & 101 & 0 & 4154 & 0 \\
\hline $\begin{array}{l}\text { Szkoła Główna Gospodarstwa } \\
\text { Wiejskiego w Warszawie }\end{array}$ & 28817 & 0 & 0 & 376 & 0 & 0 & 0 \\
\hline $\begin{array}{l}\text { Uniwersytet Rolniczy im. } \\
\text { Hugona Kołłątaja w Krakowie }\end{array}$ & 7861 & 0 & 0 & 76 & 0 & 0 & 0 \\
\hline $\begin{array}{l}\text { Uniwersytet Przyrodniczy } \\
\text { w Lublinie }\end{array}$ & 9943 & 0 & 0 & 62 & 110 & 0 & 0 \\
\hline $\begin{array}{l}\text { Akademia Wychowania } \\
\text { Fizycznego im. Jerzego } \\
\text { Kukuczki w Katowicach }\end{array}$ & 3861 & 0 & 0 & 0 & 0 & 0 & 0 \\
\hline $\begin{array}{l}\text { Akademia Wychowania } \\
\text { Fizycznego im. Eugeniusza } \\
\text { Piaseckiego w Poznaniu }\end{array}$ & 10131 & 0 & 0 & 182 & 0 & 0 & 0 \\
\hline $\begin{array}{l}\text { Akademia Wychowania } \\
\text { Fizycznego Józefa Piłsudskiego } \\
\text { w Warszawie }\end{array}$ & 4949 & 0 & 0 & 0 & 0 & 0 & 0 \\
\hline
\end{tabular}

Source: own elaboration.

Table 2

Selected statistics of social media - non-public universities

\begin{tabular}{|c|c|c|c|c|c|c|c|}
\hline Universities & 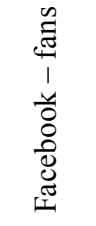 & 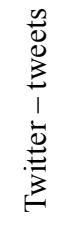 & 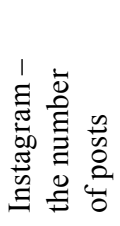 & 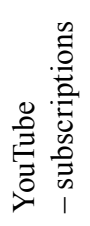 & 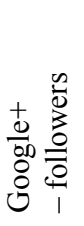 & 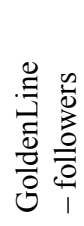 & 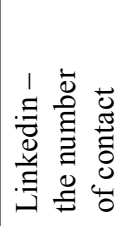 \\
\hline 1 & 2 & 3 & 4 & 5 & 6 & 7 & 8 \\
\hline $\begin{array}{l}\text { Akademia Finansów } \\
\text { i Biznesu Vistula }\end{array}$ & 15767 & 1760 & 0 & 342 & 94 & 0 & 24 \\
\hline
\end{tabular}




\begin{tabular}{|c|c|c|c|c|c|c|c|}
\hline 1 & 2 & 3 & 4 & 5 & 6 & 7 & 8 \\
\hline $\begin{array}{l}\text { Akademia } \\
\text { Humanistyczna im. } \\
\text { Aleksandra Gieysztora } \\
\text { w Pułtusku }\end{array}$ & 1909 & 0 & 0 & 0 & 0 & 0 & 0 \\
\hline $\begin{array}{l}\text { Akademia Leona } \\
\text { Koźmińskiego } \\
\text { w Warszawie }\end{array}$ & 14968 & 1750 & 459 & 576 & 0 & 0 & 465 \\
\hline $\begin{array}{l}\text { Europejska Szkoła } \\
\text { Wyższa w Sopocie } \\
\text { z siedzibą w Sopocie }\end{array}$ & 700 & 0 & 0 & 2 & 3 & 0 & 0 \\
\hline $\begin{array}{l}\text { Krakowska Akademia } \\
\text { im. Andrzeja Frycza } \\
\text { Modrzewskiego } \\
\text { w Krakowie }\end{array}$ & 7934 & 63 & 0 & 0 & 0 & 0 & 0 \\
\hline $\begin{array}{l}\text { Krakowska Wyższa } \\
\text { Szkoła Promocji Zdrowia } \\
\text { w Krakowie }\end{array}$ & 1933 & 0 & 0 & 28 & 0 & 0 & 0 \\
\hline $\begin{array}{l}\text { Podkowiańska Wyższa } \\
\text { Szkoła Medyczna } \\
\text { im. Zofii i Jonasza Łyko } \\
\text { w Podkowie Leśnej }\end{array}$ & 776 & 2 & 0 & 206 & 0 & 0 & 0 \\
\hline $\begin{array}{l}\text { Polsko-Japońska } \\
\text { Akademia Technik } \\
\text { Komputerowych }\end{array}$ & 6268 & 0 & 3 & 179 & 2 & 0 & 0 \\
\hline $\begin{array}{l}\text { Społeczna Akademia } \\
\text { Nauk z siedzibą w Łodzi }\end{array}$ & 5435 & 0 & 0 & 76 & 0 & 0 & 0 \\
\hline $\begin{array}{l}\text { SWPS Uniwersytet } \\
\text { Humanistycznospołeczny } \\
\text { z siedzibą w Warszawie }\end{array}$ & 47214 & 2081 & 0 & & 0 & 0 & 320 \\
\hline $\begin{array}{l}\text { Szkoła Wyższa im. Pawła } \\
\text { Włodkowica w Płocku }\end{array}$ & 2533 & 0 & 0 & 22 & 0 & 0 & 0 \\
\hline $\begin{array}{l}\text { Uczelnia Łazarskiego } \\
\text { w Warszawie }\end{array}$ & 9337 & 1906 & 0 & 89 & 5 & 0 & 0 \\
\hline $\begin{array}{l}\text { VIAMODA Szkoła } \\
\text { Wyższa z siedzibą } \\
\text { w Warszawie }\end{array}$ & 31801 & 0 & 296 & 0 & 0 & 0 & 0 \\
\hline $\begin{array}{l}\text { Wyższa Szkoła } \\
\text { Administracji Publicznej } \\
\text { imienia Stanisława } \\
\text { Staszica w Białymstoku }\end{array}$ & 4578 & 0 & 0 & 7 & 0 & 0 & 0 \\
\hline $\begin{array}{l}\text { Wyższa Szkoła Bankowa } \\
\text { w Gdańsku }\end{array}$ & 6877 & 1109 & 0 & 226 & 0 & 0 & 0 \\
\hline
\end{tabular}




\begin{tabular}{|c|c|c|c|c|c|c|c|}
\hline 1 & 2 & 3 & 4 & 5 & 6 & 7 & 8 \\
\hline $\begin{array}{l}\text { Wyższa Szkoła Bankowa } \\
\text { w Poznaniu }\end{array}$ & 8754 & 1100 & 0 & 226 & 0 & 0 & 0 \\
\hline $\begin{array}{l}\text { Wyższa Szkoła Bankowa } \\
\text { w Toruniu }\end{array}$ & 5820 & 1091 & 0 & 226 & 0 & 0 & 0 \\
\hline $\begin{array}{l}\text { Wyższa Szkoła Bankowa } \\
\text { we Wrocławiu }\end{array}$ & 12978 & 1082 & 0 & 226 & 0 & 0 & 0 \\
\hline $\begin{array}{l}\text { Wyższa Szkoła Biznesu } \\
\text { i Przedsiębiorczości } \\
\text { w Ostrowcu } \\
\text { Świętokrzyskim }\end{array}$ & 743 & 0 & 0 & 0 & 0 & 0 & 0 \\
\hline $\begin{array}{l}\text { Wyższa Szkoła Ekonomii } \\
\text { i Innowacji w Lublinie }\end{array}$ & 4770 & 0 & 0 & 9 & 0 & 0 & 0 \\
\hline $\begin{array}{l}\text { Wyższa Szkoła } \\
\text { Finansów i Zarządzania } \\
\text { w Warszawie }\end{array}$ & 4507 & 0 & 0 & 81 & 0 & 0 & 0 \\
\hline $\begin{array}{l}\text { Wyższa Szkoła Handlowa } \\
\text { im. Króla Stefana } \\
\text { Batorego w Piotrkowie } \\
\text { Trybunalskim }\end{array}$ & 752 & 0 & 0 & 0 & 0 & 0 & 0 \\
\hline $\begin{array}{l}\text { Wyższa Szkoła } \\
\text { Informatyki } \\
\text { i Zarządzania } \\
\text { "COPERNICUS" } \\
\text { we Wrocławiu }\end{array}$ & 549 & 0 & 0 & 0 & 0 & 0 & 0 \\
\hline $\begin{array}{l}\text { Wyższa Szkoła } \\
\text { Informatyki } \\
\text { i Zarządzania } \\
\text { z siedzibą w Rzeszowie }\end{array}$ & 11014 & 839 & 1 & 848 & 51 & 0 & 47 \\
\hline $\begin{array}{l}\text { Wyższa Szkoła } \\
\text { Menedżerska } \\
\text { w Białymstoku }\end{array}$ & 91 & 0 & 0 & 0 & 0 & 0 & 0 \\
\hline $\begin{array}{l}\text { Wyższa Szkoła } \\
\text { Menedżerska } \\
\text { w Warszawie }\end{array}$ & 2126 & 0 & 0 & 5 & 0 & 0 & 0 \\
\hline $\begin{array}{l}\text { Wyższa Szkoła } \\
\text { Przedsiębiorczości } \\
\text { i Administracji } \\
\text { w Lublinie }\end{array}$ & 2081 & 30 & 0 & 19 & 0 & 0 & 0 \\
\hline $\begin{array}{l}\text { Wyższa Szkoła } \\
\text { Techniczna } \\
\text { w Katowicach }\end{array}$ & 3258 & 0 & 38 & 0 & 11 & 0 & 0 \\
\hline
\end{tabular}




\begin{tabular}{|l|c|c|c|c|c|c|c|}
\hline \multicolumn{1}{|c|}{1} & 2 & 3 & 4 & 5 & 6 & 7 & 8 \\
\hline $\begin{array}{l}\text { Wyższa Szkoła } \\
\begin{array}{l}\text { Wychowania } \\
\text { Fizycznego i Turystyki } \\
\text { w Białymstoku }\end{array}\end{array}$ & 76 & 0 & 0 & 0 & 0 & 0 & 0 \\
\hline $\begin{array}{l}\text { Wyższa Szkoła } \\
\text { Zawodowa Łódzkiej } \\
\begin{array}{l}\text { Korporacji Oświatowej } \\
\text { w Lodzi }\end{array}\end{array}$ & 43 & 4 & 0 & 0 & 0 & 0 & 0 \\
\hline
\end{tabular}

Source: own elaboration.

The universities not found on the above list were selected for the sake of comparison. The sampling of public universities was made using the list of public universities supervised by the Minister responsible for higher education (excluding higher vocational schools). In the case of private universities, the list was based on a record of the POL-on (only universities with status active were included). A random number generator was applied, and in the case of public universities 16units were drawn, and in the case of private universities - 15. In total, 62 universities -32 public universities and 30 private universities were analyzed. Social media such as Facebook, Twitter, Instagram, YouTube, Google+, GoldenLine, Linkedin, Snapchat, Flickr, and Pinterest were accepted for the analysis. The selected social media were analyzed between 4 and 10 April 2016.

The adopted criterion of the analysis included, depending on the capabilities of a media channel, among others, being up to date, the share of comments, number of likes/ tweets/pins, number of followers, fans, views, subscriptions, and opinions reviews.

As the analysis shows, all of the examined universities have a Facebook profile. The universities that do not have a current account or place the information only from time to time, usually at least weekly or monthly, have a much smaller number of fans, and thus less or no likes at all. The study group included 6 such universities. The seventh university, which did not observe a significant amount of fans and likes, published information discouraging interaction, in the form of messages about events at the university, and most of them were not directly connected with the students. Importantly, one of the universities, which also updates its profile occasionally and does not have a significant amount of fans, has more likes in the places where the content and photos directly affect students. In other cases, these were single clicks. In this group, there is no university from the list of the most frequently chosen by the candidates within a list of MSHE, all of them are private universities. 
The universities which are placed high by MSHE ranking are more willing to undergo evaluation; only three did not start this kind of functionality - one public and two private schools. In the overall assessment, more and more universities start this functionality. It is particularly popular among the recognized university, whose students are willing to share their opinion.

A half of the analyzed schools have a Twitter account. They belong to both the group of the top universities and the units not very popular among the candidates. All but 4 post the latest information. The leading position in terms of tweets, likes, and observers is taken by Wroclaw University of Technology with the number of 10,600 tweets, 5,923 likes, and 3,944 observers.

YouTube is the second social media channel most frequently used by universities. All the schools from the list of the most popular units have an account, with as many as 5 of them not having a link to the media on the official website, and 3 of them not updating the information. Unfortunately, as many as 8 universities highly valued by candidates do not have a current record. These are often materials posted with a half-year, a year, and a longer delay. As for the updated materials, they were displayed 100 to 499 times. In the case of private universities - the University of Social Psychology and Humanities and Social University based in Warsaw, and in the case of public universities - Wroclaw University of Technology, have currently the largest number of views and subscribers. The University of Social Psychology reached as many as 7,715 subscriptions, and Wroclaw University of Technology 8,232 subscriptions. It is puzzling why the University of Silesia in Katowice, recording 5,071 subscribers, does not have updated information, taking into account the impact of such possibilities - the possession of the accounts on Facebook, Twitter, and Instagram that also have visible results of the recipients' interest in the form of fans, likes, comments etc.

It should also be noted that in the case of comments on YouTube, a part of the universities blocked this possibility for viewers.

Within the analyzed universities, public schools to a greater degree used Instagram as a tool to promote the university. Most of the visitors of this medium are observers, neither commenting nor liking. The study showed that it is not the number of posts that matters, but the idea how the photo was taken and placed. Then the followers are willing to comment and identify themselves with a certain place or situation.

Google+ has a similar number of accounts, it very often serves as a link to the YouTube channel, and information there is not updated. Only 8 universities run an active account in the social media, with only Wroclaw University of Technology having more than 1,000 followers. 
Snapchat was not a very popular channel among the students of the surveyed universities or their potential candidates. Among the respondents, only 3 public universities placed the information about their account on their pages or on Facebook, and they use this form of communication to interact, combining Snapchat with Facebook so that the actions completed there are more fixed.

In the context of other social media used by the universities, Flickr is used by: Kozminski University in Warsaw, Social Psychology University, Social and Humanities University based in Warsaw, Jagiellonian University in Krakow, and the University of Lodz; and Pinterest by: Warsaw University of Technology and Wroclaw University of Technology. The number of students who know and use these media is not great, however, showing an increased interest in this area. These are not the tools that could provide a permanent, long-term interaction with recipients.

It is also worth paying attention to the use of social media such as GoldenLine and Linkedin - mainly used for contact or obtaining information on graduates. These individuals, through their professional achievements, can encourage others (both candidates and other students) to choose a college or become more involved in their educational process. Unfortunately, only six public universities, including: the University of Adam Mickiewicz in Poznan, the University of Lodz, the University of Mining and Metallurgy of Stanisław Staszic in Cracow, the University of Economics in Krakow, Wroclaw University of Economics, and the Pedagogical University of National Education Commission in Cracow, have a current account on GoldenLine. They can boast of a large group of people observing them and the timeliness of the information they publish. The account on Linkedin is a bit more popular. There are 12 colleges, with only 6 of them having a number of contacts above 200 , and 5 of them publishing news, besides the information about the college .They include only two private universities: the University of Social Psychology and Kozminski University in Warsaw, and three public universities: the University of Silesia in Katowice, Warsaw University of Technology, and the University of Gdansk. Wroclaw University of Economics has only information, but commands are placed additionally. With the exception of the University of Silesia, these are the institutions most often chosen by the candidates in 2015.

The analysis shows that universities do not fully exploit the possibilities of social media in building relationships. There is a growing interest in owing a variety of accounts on social media channels (as compared to the research conducted in 2013 in terms of the analyzed universities), but not all of them are up to date and run in an efficient and effective manner. Public universities to a greater degree, regardless of the preferences of the candidates, use the potential of social media. In the case 
of private universities, well-managed social media are the characteristics especially of those universities that are most often selected by candidates, including the Higher School of Banking and Kozminski University. These schools have a current account on at least three basic portals, such as Facebook, Twitter, and YouTube.

Analyzing social media in the above universities, we can observe difficulties in encouraging the visitors to interact - comment on or like the posts, photos, and videos.

The study relates only to apart of the Polish market of higher education, however, it allows to draw interesting preliminary conclusions regarding the activity of universities in social media. However, the research is the basis for further indepth studies that are undertaken by the author of the article.

\section{Conclusions}

Demographic decline forces universities to more active communication, with a particular emphasis on the activities online. Apart from the need to have a professional website, the activity and professionalism in social media are essential, as they enable the university and its stakeholders to achieve a number of important benefits, including:

- lower communication barriers of users associated with a sense of greater anonymity,

- the possibility of „closer relationship” of individual stakeholder groups and their deeper relationship with the university,

- rapid flow of information (opinions, experiences, advice, and recommendations) between the university and different stakeholders, particularly important for the candidates seeking information about studies on the first and second level of studies and for choosing a major of study,

- the possibility to increase recruitment for the first year of study (according to some research the candidates acknowledge that the presence of universities on Facebook and how they interact with users have an impact on the final decision about which university they chose ${ }^{2}$ (Washenko, 2014),

- the possibility for university staff to obtain some useful information on the functioning of the university, the problems, the causes of discontent, the proposed changes, popularity of universities, reactions of users of this medium on the actions taken, loyalty to the university, the involvement of students.

2 According to research carried out in 2013 by Drake University on newly enrolled students, for one-fifth of them, the actions of universities in social media prevailed when deciding on the choice of university. 
Professionalism of activities in social media requires, among others, knowledge, experience, and creativity in this area, but also making right decisions about the number and types of portals. As follows from the results of deliberations within the "Social Media in Higher Education Roundtable Discussion" with some of the brightest minds in the industry (Social media demographics..., 2015), it is better for the university to act professionally on a few selected portals than exist on all not giving them enough attention and time. This is due to the low number of people usually employed to run social networks at universities. The choice of portals should depend mainly on demographic profile of their users, taking into account age, gender, income, place of residence, and level of education.

According to the research carried out by the authors, the universities which are chosen most often by the candidates have their current account on at least three channels of social media. Within this group, the social media are supported slightly more by public universities than the private ones. They have the activity of their loot and observers, and they work on interaction.

In the case of some universities outside the list, 6 universities have problems with timeliness on the primary channel of social media - Facebook. There are some universities that, despite having accounts, have no current information. Private universities note from 0 to 3 individual social media, and public ones from 1 individual to 5 active accounts. There are universities that work very rapidly and take care of the interaction, use different types of media channels, but, unfortunately, dominate those which use mainly Facebook.

One can say that universities are aware of the importance of social media, therefore, they decide to set up accounts and implement them in action, but not all are able to take full advantage of this medium. This may be due to the lack of knowledge on how to manage the interaction on a particular channel. One may also notice that some universities replicate messages, which sometimes does not correspond to the functionality of the social medium.

For the 'generation Z', social media are one of the main ways of communication, and hence higher education in order to reach this group must work dynamically in this area. The surveyed universities, especially those from the group of universities preferred by candidates, but also from outside of the list (in this group - mainly public ones), are on track to efficient and effective management of social media.

\section{Bibliography}

Bjørkquist, C. (2007). Stakeholder influence in higher education. Old ideas in new bottles? Dissertation: Karlstad University Studies. Retrieved from: www.kau.diva-portal.org/ smash /get/diva2:241378/FULLTEXT02 (12.04.2016). 
Chwiałkowska, A. (2013). Polskie publiczne uczelnie akademickie w mediach społecznościowych. Marketing Instytucji Naukowych i Badawczych, 4 (10), 3-21.

Chwiałkowska, A. (2014). Uczelnie w mediach społecznościowych-oczekiwania adresatów a publikowane treści. Marketing Instytucji Naukowych i Badawczych, 13 (3), 66-82.

Dixon, C. (2012). Finding the right one: mobile technology in higher education. Retrieved from: http:/er.educause.edu/articles/2012/11/finding-the-right-one-mobile-technologyin-higher-education.

Hall, H. (2016). Potencjalni kandydaci na studia jako interesariusze uczelni - aspekt relacyjny. Zeszyty Naukowe Wyższej Szkoły Bankowej w Poznaniu (in printing).

Joly, K. (2012). One design to rule them all? Responsive web design in higher education. University Business, February. Retrieved from: https://www.universitybusiness.com/ article/one-design-rule-them-all.

Kotler, Ph., Fox, K.F.A. (1995). Strategic marketing for educational institutions. New Jersey: Prentice Hall.

Kuzu, Ö.H., Gökbel, H., Güleş, H.K. (2013). Developing sustainable relations with internal and external stakeholders. Procedia - Social and Behavioral Sciences, 103 (26), 281-289.

Mainarde, E.W. (2010). An exploratory research on the stakeholders of a university. Journal of Management and Strategy, 1 (1).

Morrison, M. (2013). Why higher education needs marketing more than ever. Advertising Age, October. Retrieved from: http://adage.com/article/cmo-strategy/ higher-education-marketing/244820/.

Mróz-Gorgoń, B., Peszko, K. (2016). Marketing analysis of social media - definition consideration. European Journal of Service Management, 19 (3).

Noaman, A. (2012). Higher education marketing trends for 2012-2013. Retrieved from: http://aha.elliance.com/2012/08/09/higher-education-marketing-trends-2012-2013/\#x2 010; education\&\#x2010;marketing\&\#x2010;trends\&\#x2010;2012\&\#x2010;2013/.

Peszko, K. (2013). Ksztattowanie narzędzi komunikacji marketingowej w szkołach wyższych. Szczecin (unpublished doctoral dissertation).

Social media demographics to inform a better segmentation strategy (2015). Retrieved from: http:/sproutsocial.com/insights/new-social-media-demographics/

Tegoroczni maturzyści postawili na uczelnie techniczne (2015). Retrieved from: www.nauka. gov.pl/aktualnosci-ministerstwo/tegoroczni-maturzysci-postawili-na-uczelnietechniczne.html (3.04.2016).

Trends in higher education marketing, recruitment, and technology (2014). Hanover Research. Retrieved from: www.hanoverresearch.com/media/Trends-in-HigherEducation-Marketing-Recruitment-and-Technology-2.pdf (10.04.2016).

Uczelnie w social media - badanie 2014 (2014). Retrieved from: https://socjomania.pl/ uczelnie-w-social-media-badanie-2014 (3.04.2016).

Van Dijck, J. (2013). The culture of connectivity, a critical history of social media. Oxford: Oxford University Press. 
Washenko, A. (2013). 2 universities tell us how they are using social media. Retrieved from: http://sproutsocial.com/insights/universities-social-media/ (8.01.2014).

\section{Media społecznościowe jako narzędzie marketingu relacji współczesnych uczelni}

Słowa kluczowe: marketing relacyjny, trendy w marketingu szkół wyższych, media społecznościowe, szkolnictwo wyższe

Streszczenie. Celem artykułu jest zaprezentowanie wybranych aspektów aktywności uczelni w obszarze kreowania relacji z jej interesariuszami, ze szczególnym uwzględnieniem studentów, przy wykorzystaniu mediów społecznościowych jako kluczowej płaszczyzny komunikacji w przestrzeni online. Punktem wyjścia do analizy podjętego tematu jest zaprezentowanie istoty marketingu relacji w odniesieniu do szkół wyższych jako efektu adaptacji i ewolucji marketingu tych podmiotów rynku, jak również aktualnych trendów marketingu szkół wyższych. W artykule wykorzystano źródła wtórne oraz badania autorek artykułu, których przedmiotem była identyfikacja zakresu, intensywności i profesjonalizmu działań uczelni w płaszczyźnie mediów społecznościowych.

\section{Citation}

Hall, H., Peszko, K. (2016). Social media as a relationship marketing tool of modern university. Marketing $i$ Zarzadzanie, 5 (46), 41-56. 